\title{
Genetic selection for reduced somatic cell counts in sheep milk: A review
}

\author{
V. Riggio ${ }^{\mathrm{a}, \mathrm{b}, *}$, B. Portolano ${ }^{\mathrm{a}}$ \\ a Dipartimento Scienze Agrarie e Forestali, Università degli Studi di Palermo, Viale delle Scienze, 90128 Palermo, Italy \\ ${ }^{\mathrm{b}}$ Animal Breeding and Genomics Centre, Wageningen University, PO Box 338, 6700 AH Wageningen, The Netherlands
}

\section{A R T I C L E I N F O}

\section{Article history:}

Available online 31 January 2015

\section{Keywords:}

Mastitis

Genetic selection

Somatic cell count

Sheep

\begin{abstract}
A B S T R A C T
Mastitis is an inflammation of the udder, mainly caused by bacteria, and leads to economic loss, due to discarded milk, reduced milk production, reduced milk quality and increased health costs in both dairy sheep and cattle. Selecting for increased genetic resistance to mastitis can be done directly or indirectly, with the indirect selection corresponding to a prediction of the bacteriological status of the udder based on traits related to the infection. The most frequently used indirect method is currently milk somatic cell count (SCC) or somatic cell score (SCS). This review reports the state of the art relating to the genetic basis of mastitis resistance in sheep and explores the opportunities to use SCC as selection criterion in a breeding programme to improve resistance to mastitis in sheep, discussing the actual situation and prospects for improvement. It has been stressed, in particular, that although it is unlikely that selection for mastitis resistance by the farmers on their own will be successful, there is good prospect for genetic improvement if reliable pedigree and performance recording is implemented across flocks, combined with breeding value estimation. To achieve this, a strong and well-structured organization to implement and support the programme is essential.
\end{abstract}

(c) 2015 Elsevier B.V. All rights reserved.

\section{Introduction}

The Mediterranean Basin countries host $60 \%$ of the total world sheep and goat milk production. The dairy sheep and goat industry is usually based on local breeds, which are very well adapted to the production systems and environments. Milk production is the principal trait affecting the profitability of these industries and therefore for

\footnotetext{
is This paper is part of a supplement issue entitled "S.I.P.A.O.C. Congress 2012". Guest Edited by Antonello Carta, Maria Teresa Manfredi, Giuseppe Moniello and Massimo Trabalza-Marinucci.

* Corresponding author at: The Roslin Institute and R(D)SVS, University of Edinburgh, Easter Bush, Midlothian EH25 9RG, Scotland, UK. Tel.: +44131651 9100; fax: +441316519105.

E-mail addresses: valentina.riggio@roslin.ed.ac.uk (V. Riggio), baldassare.portolano@unipa.it (B. Portolano).
}

long time the breeding programmes have considered milk production as the major selection criterion. However, due to the EU agricultural policy and consumer demands, increased attention has been focused on traits related to the reduction of production costs, food safety and health (e.g. resistance to intramammary infections, internal parasites, scrapie, etc.). Mastitis, in particular, is one of the main infectious diseases in dairy sheep and goats as well as in dairy cattle, with respect to dairy industry and public concern, economic impact, zoonotic potential and animal welfare (Davies et al., 2009).

This review reports the state of the art relating to the genetic basis of mastitis resistance in sheep and explores the opportunities to use somatic cell count (SCC) as a selection criterion in a breeding programme to improve the resistance to mastitis in sheep, discussing the actual situation and prospects for improvement. 


\section{Mastitis and mastitis-causing pathogens}

Mastitis is an inflammation of the udder and it leads to economic loss, mainly due to discarded milk, reduced milk production and quality and increased health costs (Miller et al., 1993; Allore and Erb, 1998; Leitner et al., 2003). Rupp and Foucras (2010) reported that the total annual milk production losses due to mastitis in small dairy ruminants can be estimated to be in the region of $€ 60$ million/annum.

Mastitis can be classified as subclinical or clinical. Mastitis is subclinical when no visible changes occur in the appearance of both the milk and udder, but milk production decreases, bacteria are present in milk and the milk composition is altered (Harmon, 1994). On the other hand, mastitis is clinical when symptoms such as fever, abnormal texture and discoloration of the milk, increased temperature or pain of the quarter or udder half, and a change in milk properties occur. Generally, the incidence of clinical mastitis in cattle varies between 20 and 40\% per cow/year (Heringstad et al., 2000). In small ruminants, the annual incidence of clinical mastitis is generally lower than 5\% (Bergonier and Berthelot, 2003; Contreras et al., 2007), whereas the incidence of subclinical mastitis in these species has been estimated at $5-30 \%$ per lactation or even higher (Bergonier and Berthelot, 2003; Contreras et al., 2003).

Mastitis-causing pathogens include bacteria and nonbacterial pathogens, like mycoplasmas, fungi or viruses (Bergonier and Berthelot, 2003). Among viruses, the MaediVisna virus is one of the main causes in sheep, having being associated to mastitis, as well as chronic inflammatory lesions in the lungs, joints and brain (Radostits et al., 2007). However, given that the occurrence of non-bacterial pathogens is far less frequent, they will not be further considered in this review.

The bacterial pathogens responsible for infection of the mammary gland (in particular, coliform bacteria, staphylococci and streptococci) may be split into two main categories, according to the severity of the clinical signs, namely major and minor pathogens. Infection with major pathogens generally results in clinical illness or strong inflammatory responses and reduced milk yields, whereas minor pathogen infection is usually subclinical (White et al., 2001). Pathogens can also be categorized, depending on their aetiology, into environmental or contagious (Fox and Gay, 1993):

i) Environmental bacteria (found in the soil, faeces and bedding), which enter the teat duct from these sources and include both Gram-positive and Gramnegative bacteria such as Streptococcus non-agalactiae and coliform organisms (Escherichia coli, Klebsiella sp., Aerobacter aerogenes, Enterobacter sp.);

ii) Contagious bacteria, which are transmitted from infected quarters or halves to non-infected quarters or halves during the milking process and include Grampositive bacteria such as Staphylococcus aureus and Streptococcus agalactiae.

In cattle, coagulase-negative staphylococci (CNS) are considered to be minor pathogens; this, however, is less clear in sheep, in which CNS are considered the most common bacterial species causing both subclinical and clinical mastitis (Albizu et al., 1991; Amorena et al., 1991; Marco et al., 1991). In chronic cases, Gonzalo et al. (1998) suggested dividing the CNS into two groups with different pathogenicity between dairy sheep: NRCNS (novobiocinresistant CNS), which behave as minor pathogens, resulting in mild changes in SCC and milk yield and similar to those commonly associated with micrococci and Corynebacteria (Ziluaga et al., 1998). Also NSCNS (novobiocin-sensitive CNS), which cause more substantial changes in SCC and loss in milk yield, similar to those associated with the classic major pathogens (Peris et al., 1996).

\section{Selection criteria to select for mastitis resistance}

Mastitis resistance is a complex trait, involving both genetic and environmental factors, including infection pressure. In the broadest sense, resistance could be defined as the ability to avoid any infection and/or the quick recovery from an infection (Rupp and Boichard, 2003). It involves different components, namely avoiding entry of the pathogen into the mammary gland, mounting an immune response capable of limiting its development in the udder and clearing the infection, as well as controlling the pathogenic effects of the infection, such as, e.g., tissue damage (Rupp and Foucras, 2010).

Selecting for increased genetic resistance to mastitis can be done directly or indirectly. Direct selection relates to the diagnosis of the infection. The actual trait (e.g. bacteriological examination of milk and/or observation of clinical cases of mastitis) is measured on the animal or its relatives. Indirect selection relates to a prediction of the bacteriological status of the udder, based on traits related to the infection (e.g. inflammatory parameters). In this case, an indicator trait for mastitis is measured on the animal itself or its relatives (de Haas, 2003). A direct bacteriological assay is the recommended method of diagnosis of mastitis (GonzálezRodríguez and Cármenes, 1996), as it is believed to provide precise and exhaustive information on infected quarters and/or halves and the pathogens involved. However, it is rarely used for genetic purposes, because it is difficult to implement on a large scale. It also has limitations because of the requirement of intensive labour, the time delays for culture to occur and the costs involved with bacteriology (McDougall et al., 2001). Moreover, it has been shown that bacterial shedding is variable and levels may sometimes be too low to be detected by conventional techniques (Rupp and Foucras, 2010). Therefore, although the bacteriological examination is often considered to be the 'golden standard' for routine detection and identification of mastitis pathogens, it has to be taken into account that even good quality bacteriological data will have true sensitivity and specificity values somewhat less than one, i.e. some cases will be missed and others will be misdiagnosed as infected when they are not (Riggio et al., 2010).

Simple, indirect methods have been widely applied, based on the evaluation of the degree of inflammation or of internal mammary lesions (De la Cruz et al., 1994). Their accuracy is usually established by bacteriological analysis 
as a reference method. Among these methods, the most frequently used to detect mastitis is SCC.

\section{Biological signification of SCC}

Somatic cells normally occur in milk of both cattle and small ruminants. Somatic cells consist of many types of cells, including polymorphonuclear leukocytes (PMN), macrophages, lymphocytes, eosinophils and various epithelial cells from the mammary gland. Cells in milk from a healthy udder are mainly represented by mammary gland epithelium and drain canal cells. Recently, Leitner et al. (2012) showed that epithelial cells accounted for $\sim 50 \%$ of the cells in goats and cows, whereas in sheep this was $\sim 80 \%$. These researchers suggested that sheep shed more epithelial cells into milk in comparison to cows and goats, probably because these cells play an important role in the immune response. According to Walawski (1999), only $8 \%$ of the cells are leukocytes and less than $1 \%$ are macrophages in cattle. However, in a more recent study, Leitner et al. (2012) showed that in bacteria-free animals at midlactation, goats had the highest number of leukocytes and PMN. Sheep, on the other hand, had the lowest and cows were intermediate between sheep and goats. It has also been reported that PMN are the major cell population during early inflammation and play a protective role against infectious diseases in the mammary gland (Kehrli and Shuster, 1994; Persson-Waller et al., 1997). Experimental intramammary infection of sheep with $S$. aureus or $E$. coli has been shown to induce a significant increase in PMN within $24 \mathrm{~h}$ of infection (Persson-Waller et al., 1997).

Determination of the differential cell count in milk is another useful approach to evaluate the proportion of leukocytes during inflammation and thus the immune status of the mammary gland. In ewe milk samples, flow cytometry was used to detect the percentage of PMN, macrophages and lymphocytes in bulk and individual milk with different concentrations of somatic cells (Albenzio et al., 2009, 2011; Albenzio and Caroprese, 2011).

The concentration of somatic cells in milk is defined as SCC and it is expressed as thousands of cells per millilitre of milk. The measure of SCC has the following properties:

it can be routinely recorded in most milk-recording systems;

the heritability of SCC is higher than the heritability of the direct trait (i.e., mastitis incidence);

it is usually an indicator of both clinical and subclinical infections.

What is reported thus far shows why SCC is usually considered as a good predictor of mastitis occurrence (milk SCC reflects the number of neutrophils migrating from blood to the mammary gland in response to infection). However, numerous factors influence the SCC level of both infected and non-infected animals, such as the physiological status of the host, the infection status and the pathogen. It is, therefore, difficult to interpret single measures and define fixed thresholds, as distributions of the SCC of infected and non-infected animals overlap considerably (Riggio et al., 2010; Rupp and Foucras, 2010). This aspect will be further analyzed in the next sections. From these considerations, it follows that repeated measures or lactation average are usually preferred for both diagnosis and genetic purposes.

The distribution of SCC is positively skewed, whereas conventional statistical methods usually accommodate normally distributed data. In order to obtain a distribution which closely resembles a normal distribution, the SCC is log-transformed to somatic cell score (SCS). The formula commonly used is: $\mathrm{SCS}=\log _{2}(\mathrm{SCC} / 100)+3$ (Ali and Shook, 1980). However, other researchers have used either $\log _{e}$ or $\log _{10}$ logarithmic transformation (Samoré, 2003).

\subsection{SCC in sheep}

While cattle SCC values between 250 and $300 \times 10^{3}$ cells/mL are reported as most satisfactory discrimination thresholds between healthy and infected udders, sheep do not have a widely accepted threshold. Some evidence has been provided that healthy ewes have normally higher SCC than cows (Maisi et al., 1987; Fthenakis et al., 1991; González-Rodríguez et al., 1995). Bufano et al. (1996) showed that a high SSC ( $>1$ million/mL) occurs in healthy sheep and goat milk, especially towards the end of lactation. While Riggio et al. (2010) reported that the SCC can be high, even when ewes are not infected, suggesting that a healthy animal can wrongly be diagnosed as infected based on SCC.

On the other hand, considering subclinical mastitis, Leitner et al. (2008) suggested that, while in dairy cows subclinical mastitis is largely ignored, because the increase in SCC in infected glands is modest (about 300-500 $\times 10^{3}$ cells $/ \mathrm{mL}$ ) and the mixing with the milk from non-infected quarters is sufficient in most cases to appreciably lower the effect of SCC at the cow level. In sheep and goats, which have only two mammary glands, mixing of milk with high SCC coming from an infected gland with a low SCC from a healthy gland might be insufficient to reduce the SCC at the animal level. However, whether these high SCC are a consequence of the fairly generalized lack of preventive management measures against subclinical mastitis in sheep flocks or whether a higher cell discrimination threshold is required for sheep milk, has not been established.

It is important to highlight, however, that the choice of a threshold in the cattle industry was mostly driven by monetary factors. While little knowledge has been available on the significance of other factors in keeping farmers motivated to improve mastitis management (Valeeva et al., 2007). In sheep, some studies reported that similar payment systems (e.g. reduced milk prices, if the SCC of the bulk tank milk exceeds certain thresholds) are becoming common (Legarra et al., 2007; Pirisi et al., 2007). However, the current milk payment system of most breeds and countries is still based only on milk yield and not on SCC level. This makes it more difficult to choose a threshold to discriminate between healthy and infected udders, which can be worldwide accepted. Some researchers (Fthenakis et al., 1991; Jones, 1991) reported discrimination values between healthy and infected glands ranging from 500 to $1600 \times 10^{3}$ cells $/ \mathrm{mL}$, while others (Bergonier et al., 1994; De la Cruz et al., 1994; Pengov, 2001) reported values similar to those for cows $\left(200-300 \times 10^{3}\right.$ cells $\left./ \mathrm{mL}\right)$. 
González-Rodríguez et al. (1995) suggested that breed differences in SCC do exist. Considering several breeds, these researchers reported the value of $300 \times 10^{3}$ cells $/ \mathrm{mL}$ as the most suitable threshold of discrimination for total SCC data. However, within each breed, the most suitable threshold was $400 \times 10^{3}$ cell $/ \mathrm{mL}$ for Assaf and Castellana and $200 \times 10^{3} \mathrm{cell} / \mathrm{mL}$ for the Churra sheep breeds.

Recently, it was also suggested that SCC diagnostic effectiveness (SCC ability to detect whether or not intramammary infections occur) may be assessed to a degree without having to commit to a single threshold with the use of average indices based on receiver-operating characteristic (ROC) curves (Riggio et al., 2013). These researchers identified different optimal SCS thresholds, ranging from 2.81 to 3.33 , depending on the trait definition (e.g. SCS for the whole sample, SCS for samples with minor pathogen infections and SCS for samples with major pathogen infections). It was suggested that different SCC (and therefore SCS) thresholds should be used when considering mastitis caused by minor or major pathogens.

\section{Genetic parameters of SCC and mastitis and correlations with other traits in sheep}

\subsection{Genetic parameters of SCC and mastitis in sheep}

Genetic studies of SCC in dairy sheep are more recent and less frequent than in dairy cattle. Heritability estimates, based on repeatability test-day models, range from 0.04 to 0.16 for several breeds including the Churra (Baro et al., 1994; El-Saied et al., 1998; Othmane et al., 2002), the Manchega (Serrano et al., 2003), the East Friesian (Hamann et al., 2004) and the Valle del Belice sheep breeds (Riggio et al., 2007). Other studies reported similar or slightly higher heritability estimates (from 0.11 to 0.18 ) for the average SCS during lactation, for Chios (Mavrogenis et al., 1999), Lacaune (Barillet et al., 2001; Rupp et al., 2003a), Latxa (Legarra and Ugarte, 2005) and Manech Red Faced ewes (Barillet et al., 2008). These heritability estimates are comparable to those reported in literature for cattle either with test-day (Carnier et al., 1997; Mrode et al., 1998) or lactation models (Rupp and Boichard, 1999). Moreover, in cattle, it has been shown that heritability estimates for SCS are usually higher than heritability for the direct trait (i.e. mastitis incidence). Therefore, when only considering the heritability, these results suggest that selection for SCS (as indicator of mastitis) has to be preferred over selection for the direct trait. However, before conclusions can be drawn, correlations between traits should be considered.

In cattle, for example, genetic correlations between SCS and the incidence of clinical mastitis vary from moderate to high, with an average of approximately 0.7 (Rupp and Foucras, 2010). These results, therefore, confirm that, although SCS and mastitis are not the same trait, SCS can be used as a selection criterion in a breeding programme for mastitis resistance in cattle. In sheep, however, no estimates of genetic correlations between SCC and clinical and subclinical mastitis incidence have been reported in the literature.

On the other hand, when considering data on intramammary infections assessed by bacteriological analyses, only few results are found in the literature. Published studies refer more directly and exhaustively to udder health status. In cattle, heritabilities for intramammary infections varied from 0.02 to 0.04 as reported by Weller et al. (1992). Somewhat higher (0.10-0.20) as quoted by Detilleux et al. (1994) and Wanner et al. (1998). In sheep, an estimate of 0.09 for the infection status assessed by bacteriological analyses was reported by Riggio et al. (2010) and Tolone et al. (2013) in the Valle del Belice breed. However, it was reported that with imperfect sensitivity and, particularly, specificity, the heritability of liability is likely to be substantially underestimated. In other words, there may truly be more genetic variation for the liability to mastitis than the field data suggests (Riggio et al., 2010). Tolone et al. (2013) reported a genetic correlation between SCS and the infection status, as assessed by bacteriological analyses of 0.93 , suggesting that selection for low SCS could also lead to a reduced incidence of mastitis. These results, therefore, indicate that selection for reduced SCS can help to reduce mastitis incidence. In this regard, results by Rupp et al. (2009) from a firstlactation survey in dairy sheep have provided evidence that selection based on SCS estimated breeding values (EBVs) may help to improve resistance to clinical and subclinical mastitis. Low SCS line animals showed a lower incidence of clinical mastitis, a lower prevalence of mammary abscesses and subclinical intramammary infections, especially at parturition. A better ability to recover from intramammary infections contracted during lactation and a lower SCS in bacteriologically positive samples was also found. These results were also emphasized by Riggio et al. (2010), suggesting that animals with a high SCS in bacteriologically negative samples, are more prone to mastitis. Therefore, the approach of selecting animals for decreased SCS is justified and should help to reduce the prevalence of mastitis, even in the absence of knowledge about the infection status of the animal. This is in agreement with what previously reported in cattle. Philipsson et al. (1995) have estimated a linear relationship between SCC and the occurrence of clinical mastitis, concluding that the selection for lower SCC was desirable and that a lower level of SCC reflects a reduced incidence of infection, rather than a reduced ability to react to it. Moreover, Rupp et al. (2000) concluded that cows with the lowest mean SCC in the first lactation had the lowest risk for clinical mastitis in the second lactation. These results, therefore, suggest that breeding goals should favour animals with the lowest observed SCC. Nevertheless, it has been stated that by decreasing the milk SCC to very low levels by selection, could impair the animal's capacity to combat intramammary infection. Some of the milk resident cells, such as macrophages, are essential in initiating the inflammatory process in response to intramammary invading pathogens. Therefore, it might be useful to monitor if this (i.e. selection for the lowest SCC level) does not affect the ability to resist infections. A better understanding of the defence mechanisms affected or modified by such a selection could be indeed helpful, to predict indirect responses on udder health in the long term and, if necessary, to modify the selection modality and criteria accordingly. It could also be important to monitor the actual mastitis incidence in the population by, for example, collecting information on the infection status at regular 
intervals to ensure that selection on correlated traits still results in the desired improvement of udder health.

When deciding upon the most appropriate trait to select for, one should also take into account the sociocultural background of the farmers. Compared to the collection of information on infection status or clinical mastitis, it is easier, cheaper and less time-consuming for farmers to collect information on SCC. This can be regularly recorded during milk recording at a low cost. In this case, therefore, farmers would likely be more willing to cooperate because of the low costs and high frequency of recording. In contrast, samples for determining the infection status have to be collected with more care, than samples for SCC. The implementation of a protocol for collecting such samples by farmers may be difficult, requiring more commitment in order to ensure sufficient quality of sample collection. It may therefore also be necessary, in this case, to have these samples collected by more qualified persons, with the obvious disadvantages of higher costs and additional time by the farmers.

It is important to highlight, however, that in most of the sheep breeds, current selection is mainly practised on a "within farm" basis and based on the performance of the ewes. In this situation, according to the considerations drawn so far, it is unlikely that selection for mastitis resistance will be successful, independent of the use of infection status or SCS. Based on the above considerations, therefore, the implementation of a well-structured breeding programme needs to be realized, in order to guarantee reliable pedigree recording and performance registration. At present, only a few dairy populations worldwide, mainly located in the Mediterranean region or in North America, have the required organization to allow the development of a large-scale recording and genetic evaluation (Rupp and Foucras, 2010). To current knowledge, the French Lacaune breed is the only small ruminant dairy breed selected for increased udder health (Rupp et al., 2002)-with genetic evaluations for the lactation mean SCS, run since 2002, based on a simplified recording system for SCC and implemented in the same way as that for milk fat and protein content (Rupp et al., 2002).

\subsection{Genetic correlations between SCS and other traits}

Although farmers select on several traits, based on own performance, milk yield is currently the most important selection criterion, for which phenotypic records are collected and breeding values are estimated, in most dairy sheep breeds. Barillet (1997) suggested that the introduction of milk composition traits and/or functional traits (e.g. resistance to mastitis) as selection objectives should be addressed only when a breeding programme has reached an asymptotic annual genetic gain for milk yield. However, this ignores the correlated response in other economically important traits, resulting from selection on milk production only. To quantify the likely correlated responses, it is important to determine the genetic correlations between different traits.

Unlike bovine mastitis, where the genetic antagonism between SCS and milk production traits is well documented, genetic correlation estimates between milk production and mastitis traits are quite inconsistent across dairy sheep studies. Published genetic correlations between SCS and milk yield range from positive, i.e. antagonistic, to negative (Baro et al., 1994; El-Saied et al., 1998, 1999; Barillet et al., 2001; Rupp et al., 2003a; Riggio et al., 2007).

Another interesting aspect to consider is the correlation between SCS and udder conformation traits, which are favourable according to literature (Legarra and Ugarte, 2005; Sechi et al., 2007). Results suggest that udders with what is perceived to be a good shape are less affected by subclinical mastitis. Pendulous udders have been associated with an increase in SCC (Casu et al., 2010; Huntley et al., 2012). Pendulous and deep, poorly attached udders are difficult to milk and may cause sudden cluster falling, teat-end impacts and subsequent bacterial infections (Bergonier et al., 2003). In addition, these udders are more prone to injuries (Legarra and Ugarte, 2005). However, this is a bit controversial, as Huntley et al. (2012) showed that teat lesions were not significantly associated with a change in udder half SCC, suggesting that teat lesions do not increase the risk of bacterial invasion of the udder.

\section{Alternative statistical modelling for SCC/SCS}

In using SCC as an indicator of mastitis, the dynamic nature of mastitis is often ignored in the statistical analysis. It has been reported that both clinical and subclinical mastitis cause deviations from a typical curve of SCC (de Haas et al., 2004). In this respect, the use of individual SCC testday records is an improvement, compared to the average of SCC records collected during a lactation. However, Urioste et al. (2010) reported that the use of test-day SCC can still make it difficult to identify short-duration infections, as SCC is often only recorded at approximately monthly intervals. Therefore, Urioste et al. (2010) suggested exploring alternative traits derived from the SCC curve (e.g. traits designed to capture SCC base levels and variation along the curve, time and level of infection, and time of recovery). Ideally, these alternative traits should be able to accommodate sudden and drastic changes in SCC, which in turn may improve the diagnosis of mastitis and hence increase genetic progress in mastitis resistance. There are, however, limitations to the use of these alternative traits on commercial farms. If it is true that the shortcoming of SCC is that it is only recorded monthly, making it difficult to identify short-duration infections, then these alternative traits are unlikely to contain more information as they are based and designed on the same original information (i.e. test-day SCC). Moreover, ewes are milked (and, therefore, SCC records available) only once lambs are fully weaned, which could lead to an early misclassification of healthy and infected animals. Therefore, these alternative traits can probably be explored, used and better exploited on experimental farms, where the SCC records can be collected more frequently.

In the genetic evaluation of SCS, information collected on healthy (i.e. non-infected) and infected animals, is treated equally. However, several researchers suggested that, in cattle, SCS in healthy and infected animals are different traits (Detilleux and Leroy, 2000; Boettcher et al., 
2007; Madsen et al., 2008). This was also confirmed in sheep by Riggio et al. (2010), who showed that SCS in healthy and infected animals can indeed be considered as different traits-with different heritabilities, and with a genetic correlation between bacteria negative and bacteria positive SCS of 0.62 . Whilst this genetic correlation is moderately positive, it is significantly less than unity, suggesting that bacteria negative and bacteria positive SCS are not the same trait. The genetic evaluation of SCS can be improved when this non-unity genetic correlation is taken into account. In most countries, however, cases of mastitis are not routinely recorded in a systematic manner. The lack of information on the infection status is a limitation in selecting directly for mastitis resistance. It implies that when using SCS as an indicator of mastitis, no distinction can be made between SCS data from infected and non-infected animals.

When information on the infection status is not available, SCS may be regarded as a mixture of observations from animals with unknown health status, i.e. with and without mastitis. Mastitis infection would produce a deviation from the SCS baseline level, i.e. an observed test-day SCS can be regarded as resulting from effects of a baseline SCS (a continuous trait) and a deviation caused by a binary process (healthy or infected status). Detilleux and Leroy (2000) have shown that a finite mixture model can account for these differences and can represent a latent structure in a set of data, whereby observations may belong to one of several distributions-possibly differing in mean, variance and even the type of distribution (McLachlan and Peel, 2000). Recently, ten Napel et al. (2009) showed that there is indeed evidence in the distribution of SCC values that some SCC are an indication of an infected udder or quarter and others are indicative of a response to infection or a recovery from an infection. These researchers highlighted that by describing the observed distribution by a mixture of four normal and one exponential distributions provides an opportunity to distinguish between noninfected animals and animals infected with minor or major pathogens.

Using mixture models, therefore, the selection for reduced mastitis incidence may be based on the probability of mastitis given SCS, rather than selection for lowest possible SCS. More recent research has also been done to extend the ideas of Detilleux and Leroy (2000) to develop a finite mixture model for SCS, using a Bayesian approach (Ødegård et al., 2003; Gianola et al., 2004; Boettcher et al., 2007). Boettcher et al. (2007) tested four different mixture models and all were found to be more appropriate for analysis of SCS data, than the standard linear model. Moreover, although correlations of ca. 0.90 were recorded between breeding values from the mixture and linear models, changes in ranking of the higher ranked sires were reported, showing that practical benefits would be realized with the adoption of a mixture model for genetic evaluation. However, it has to be highlighted that although mixture models are potentially useful and a good alternative for analysis of SCS data, they require good data recording. Moreover, these models may be difficult to implement in practical breeding values estimations, because of computational limitations.

\section{Actual situation and prospects for improvement}

An accurate selection criterion must be a relevant biological trait genetically well correlated to mastitis resistance, exhibit sufficient genetic variability and have operational properties, such as easy and cheap measuring procedure on a large scale. Based on these considerations, SCC is the most widely used criterion to achieve better udder health. Repeated SCC data are indeed routinely recorded for individuals as part of milk recording schemes. Nevertheless, it is important to keep in mind that the genetic response will always be limited-as breeding objectives still favour milk quantity and content from an economic point of view.

In setting up a breeding programme, however, there are other issues that are important to take into account. Technical and infrastructural related issues, for example, are the greatest bottlenecks in genetic improvement programmes for most of the sheep farming systems: small flock sizes, poor pedigree and performance recording, lack of clear breeding goals, lack of or poor infrastructures. These are all factors that contribute to the low participation of farmers in breeding schemes, which in turn makes achieving within-breed genetic improvement highly challenging.

Whereas artificial insemination (AI) is a common reproductive technique in dairy cattle, in dairy sheep its application is limited to experimental farms. Due to the low use of $\mathrm{AI}$, the diffusion rate of a ram is from 100 to 1000 times lower than that of a bull (Carta et al., 2009). The limited use of AI, therefore, reduces the progeny group size of rams and is in general associated with poor pedigree recording, which negatively affects the accuracy of breeding value estimates (Van Vleck, 1970; Lee and Pollak, 1997). Many flocks rely on a few males, and it is not possible to know with certainty which ram is the sire of an animal. In dairy cattle, it has been reported that paternity errors can reach up to $20 \%$ of registered animals (Ron et al., 1996) and this percentage is probably even higher in sheep, drastically reducing the genetic gain and the success of breeding programmes. To overcome this problem, it is possible for farmers to manage natural mating by grouping ewes with a single ram (i.e., mating group) during the mating period. This management strategy would make it easier to determine the correct sire of a lamb, based on the lambing date. However, the poor infrastructures on the farms in general do not allow for the implementation of these strategies. As an alternative, it may be possible to use DNA testing for pedigree verification or pedigree assignment in cases of unrecorded mating or the use of multiple sires. Procedures have been already developed for both goats and sheep (Glowatzki-Mullis et al., 2007; Rosa et al., 2013), as well as dogs (DeNise et al., 2004), horses (Tozaki et al., 2001; Seyedabadi et al., 2006) and cattle (Van Eenennaam et al., 2007).

Another problem encountered in genetic evaluation of sheep flocks is the poor genetic connections between flocks, which result from the limited exchange of rams between farms. This could be overcome by AI, but as discussed earlier the uptake of AI is low. This implies that improvements in genetic connections need to come from 
exchanging rams between farms. However, farmers do not see it as favourable to exchange rams between flocks, as they usually think they have the best individuals. An alternative would be to implement a selection scheme based on the pyramid management of the population, which is nowadays considered the most efficient selection scheme for local dairy sheep (Barillet, 1997). In this scheme, the nucleus flocks are at the top of the breeding pyramid. In these flocks, pedigree and milk recording are implemented, and breeding value estimations are carried out to generate genetic progress in these flocks. The genetic progress would be then disseminated to commercial flocks through AI or natural-mating rams originated from nucleus flocks. A potential problem in the implementation of this scheme is that farmers would need to be convinced regarding the superior quality of the rams from the nucleus flock. However, it is likely that farmers will be willing to cooperate in such a scheme once they experience the quality of the breeding products. It would even be easier to realize such a scheme if it were technically or financially supported by the Government, Breeder Associations or the University. The support by such an Institution would reassure farmers, who sometimes just need to feel that their interests are taken into account.

When implementing a nucleus breeding scheme, an important aspect is the genotype by environment $(G \times E)$ interaction. $G \times E$ interactions could reduce the benefits for commercial farmers of genetic progress generated in the nucleus flock. One of the methods used to quantify $\mathrm{G} \times \mathrm{E}$ is the estimation of genetic correlations $\left(r_{\mathrm{g}}\right)$ between traits measured in different environments. When $r_{\mathrm{g}}$ between the phenotypic values of the same trait expressed in different environments is high, i.e. equal or close to 1 , then there is no $\mathrm{G} \times \mathrm{E}$ (Robertson, 1959). On the other hand, low $r_{\mathrm{g}}$ values indicate $G \times E$, i.e. phenotypes expressed in different environments are expressions of different traits. Mulder and Bijma (2005) estimated that an $r_{\mathrm{g}}$ of 0.80 between two environments results in $20 \%$ less genetic gain for a trait in dairy cattle, when breeding stock are selected in another environment. Mulder et al. (2006) demonstrated that in dairy cattle, when $r_{\mathrm{g}}$ between environments are between 0.50 and 0.70 , a single breeding programme with progeny testing bulls in different environments would be optimal to breed for general adaptability. However, when $r_{\mathrm{g}}$ between environments is lower than 0.50 , environmentspecific breeding programmes are necessary to breed for specific adaptability. Therefore, to realize a pyramid selection scheme for any breed, it would be important to make sure that the environment of the nucleus flocks is comparable to that at the commercial farms.

Concerning diseases and disease resistance, quantifying and accounting for the impact of environmental factors is an important part of identifying and measuring true host genetic variation in resistance to the disease under study. There is a risk of bias in genetic parameter estimates and lost opportunities in identifying individuals with extreme genetic risk, when these environmental factors are not correctly taken into account (Bishop and Woolliams, 2010). It is therefore necessary to determine the "optimal exposure level" in order to select for mastitis resistance. Of course it would not be good to have all animals being infected; however, on the other hand, if no animals are affected, then there is no information upon which to base the selection. It is important to realize that a lack of exposure simply means that individuals do not have the opportunity to express their genetic merit for resistance, with potentially highly susceptible individuals being (wrongly) classified as resistant, simply because they are healthy (Bishop and Woolliams, 2010). These researchers have also demonstrated that whilst true presence/absence of a disease, given exposure to infection, is largely a function of the immune response, the actual prevalence of the disease and the estimable genetic variation between animals will be influenced by variable exposure and the sensitivity of diagnosis.

In implementing a breeding scheme for mastitis resistance, it has to be taken into account that measurements of phenotypic indicators for mastitis resistance are time- and labour-intensive. Therefore, the use of genetic markers to indicate resistance or susceptibility to mastitis or to better exploit the phenotypic information through genomic selection (GS) is an attractive proposition (Goddard and Hayes, 2007). At present, however, the available literature on GS and molecular markers for mastitis resistance mainly refer to dairy cattle (Klungland et al., 2001; Boichard et al., 2003; Schulman et al., 2004). In sheep, quantitative trait loci (QTL) influencing SCS have recently been detected (Rupp et al., 2003b; Gutierrez-Gil et al., 2007; Raadsma et al., 2009).

There is currently widespread excitement regarding the potential for GS to provide new approaches for the improvement of sustainability traits in Holstein dairy cows. Many breeding programmes worldwide have already implemented GS. However, it is important to recognize that it is not obvious how GS can be implemented in small ruminant species. An important limitation of applying GS to sheep is that a reference population of considerable size would be required. In dairy cattle, for example, reference populations of over 4000 progeny tested young bulls are available, and this scale would be difficult to achieve in sheep. However, nowadays, thanks to the development of high-density SNP arrays with tens of thousands of genetic markers spread across the genome, research is moving to the direction of GS in sheep as well, as such arrays have also proved to be very powerful, with even a small number of animals. In a GS study conducted on the Lacaune breed on three traits (milk yield, fat content, SCS), Duchemin et al. (2012) have demonstrated that molecular markers can be effectively used to improve current selection methods. Using a reference population of about 2500 proven rams and about 44,000 SNP, it was reported that accuracies of GEBV for males at birth can be improved from +18 to $+25 \%$, according to the traits.

\section{Conclusions}

Although results reported in the literature for sheep are less frequent than for cattle, it seems to be accepted that selection for reduced SCS would lead to a reduced mastitis incidence. This review, however, highlights a number of elements that need to be considered when setting up a breeding programme for mastitis resistance, using SCS as an indicator. Besides the importance of knowledge of 
both genetic and environmental aspects of the traits considered, the need has been stressed for having a strong and well-structured organization to implement and support the programme. The heritabilities of the traits of interest, either SCS or infection status, are indeed low. Therefore, it is unlikely that selection for mastitis resistance by the farmers on their own will be successful. However, there is a good prospect for genetic improvement at farm level, when reliable pedigree and performance recording is implemented across flocks and combined with breeding value estimation. This system requires cooperation between the farmers and technical support from an independent organization.

\section{Conflict of interest}

None.

\section{References}

Albenzio, M., Caroprese, M., 2011. Differential leukocyte count for ewe milk with low and high somatic cell count. J. Dairy Res. 78, 43-48.

Albenzio, M., Santillo, A., Caroprese, M., d'Angelo, F., Marino, R., Sevi, A., 2009. Role of endogenous enzymes in proteolysis of sheep milk. J. Dairy Sci. 92, 79-86.

Albenzio, M., Santillo, A., Caroprese, M., Schena, L., Russo, D.E., Sevi, A., 2011. Composition, indigenous proteolytic enzymes and coagulating behaviour of ewe milk as affected by somatic cell count. J. Dairy Res. $78,442-447$

Albizu, I., Penadés, J.R., Baselga, R., Amorena, B., Marco, J.C., 1991. Incidencia de mamitis subclínica en ovejas Rasa Aragonesa (Incidence of subclinical mastitis in Rasa Aragonese sheep). Med. Vet. 12, 723-728.

Ali, A.K.A., Shook, G.E., 1980. An optimum transformation for somatic cell concentration in milk. J. Dairy Sci. 63, 487-490.

Allore, H.G., Erb, H.N., 1998. Partial budget of the discounted annual benefit of mastitis control strategies. J. Dairy Sci. 81, 2280-2292.

Amorena, B., García de Jalón, J.A., Baselga, R., Ducha, J., Latre, M.V., Ferrer L.M., Sancho, F., Mânsson, I., Krovacek, K., Faris, A., 1991. Experimental infection in mammary glands with ovine mastitis bacterial strains: evaluation of a rabbit model. J. Comp. Pathol. 104, 289-302.

Barillet, F., 1997. Genetics of Milk Production, The Genetics of Sheep.

Barillet, F., Astruc, J.M., Lagriffoul, G., Aguerre, X., Bonaïti, B., 2008. Selecting milk composition and mastitis resistance by using a part lactation sampling design in French Manech red faced dairy sheep breed. In: Proceedings 36th ICAR Biennal Session, Niagara Falls, USA, 13, pp. 129-135.

Barillet, F., Rupp, R., Mignon-Grasteau, S., Astruc, J.M., Jacquin, M., 2001. Genetic analysis of mastitis resistance and somatic cell score in French Lacaune dairy sheep. Genet. Sel. Evol. 33, 397-415.

Baro, J.A., Carriedo, J.A., San Primitivo, F., 1994. Genetic parameters of test day measures for somatic cell count, milk yield, and protein percentage of milking ewes. J. Dairy Sci. 77, 2658-2662.

Bergonier, D., Berthelot, X., 2003. New advances in epizootiology and control of ewe mastitis. Livest Prod. Sci. 79, 1-16.

Bergonier, D., De Cremoux, R., Rupp, R., Lagriffoul, G., Berthelot, X., 2003. Mastitis of dairy small ruminants. Vet. Res. 34, 689-716.

Bergonier, D., Van DeWiele, A., Arranz, J.M., Barillet, F., Lagriffoul, G. Condorcet, D., Berthelot, X., 1994. Detection of subclinical mammary infections in the ewe by mean of somatic cell counts: proposal of physiological thresholds. In: Proc. Int. Symp. on Somatic Cells and Milk of Small Ruminants, Bella, Italy. Wageningen Pers, Wageningen, The Netherlands, pp. 41-47.

Bishop, S.C., Woolliams, J.A., 2010. On the genetic interpretation of disease data. PLoS ONE, 5.

Boettcher, P.J., Caraviello, D., Gianola, D., 2007. Genetic analysis of somatic cell scores in US Holsteins with a Bayesian mixture model. J. Dairy Sci. 90, 435-443.

Boichard, D., Grohs, C., Bourgeois, F., Cerqueira, F., Faugeras, R., Neau, A., Rupp, R., Amigues, Y., Boscher, M.Y., Leveziel, H., 2003. Detection of genes influencing economic traits in three French dairy cattle breeds. Genet. Sel. Evol. 35, 77-101.

Bufano, G., Dario, C., Laudadio, V., 1996. The characterisation of Leccese sheep: variations of chemical composition and lactodynamographic parameters in milk as related to somatic cell counts. In: Rubino, R. (Ed.), Somatic Cells and Milk of Small Ruminants. , pp. 301-304.
Carnier, P., Bettella, R., Cassandro, M., Gallo, L., Mantovani, R., Bittante, G., 1997. Genetic parameters for test day somatic cell count in Italian Holstein Friesian cows. In: Proc. 48th EAAP, vol. 3, Vienna, p. 141.

Carta, A., Casu, S., Salaris, S., 2009. Invited review: current state of genetic improvement in dairy sheep. J. Dairy Sci. 92, 5814-5833.

Casu, S., Sechi, S., Salaris, S.L., Carta, A., 2010. Phenotypic and genetic relationships between udder morphology and udder health in dairy ewes. Small Rumin. Res. 88, 77-83.

Contreras, A., Luengo, C., Sánchez, A., Corrales, J.C., 2003. The role of intramammary pathogens in dairy goats. Livest Prod. Sci. 79, 273-283.

Contreras, A., Sierra, D., Sánchez, A., Corrales, J.C., Marco, J.C., Paape, M.J., Gonzalo, C., 2007. Mastitis in small ruminants. Small Rumin. Res. 68, 145-153.

Davies, G., Genini, S., Bishop, S.C., Giuffra, E., 2009. An assessment of opportunities to dissect host genetic variation in resistance to infectious diseases in livestock. Animal 3, 415-436.

de Haas, Y., (PhD thesis) 2003. Somatic cell count patterns. Improvement of udder health by genetics and management. Wageningen University.

de Haas, Y., Veerkamp, R.F., Barkema, H.W., Grohn, Y.T., Schukken, Y.H., 2004. Associations between pathogen-specific cases of clinical mastitis and somatic cell count patterns. J. Dairy Sci. 87, 95-105.

De la Cruz, M., Serrano, E., Montoro, V., Marco, J., Romeo, M., Baselga, R., Albizu, I., Amorena, B., 1994. Etiology and prevalence of subclinical mastitis in the Manchega sheep at mid-late lactation. Small Rumin. Res. 14, 175-180.

DeNise, S., Johnston, E., Halverson, J., Marshall, K., Rosenfeld, D., McKenna, S., Sharp, T., Edwards, J., 2004. Power of exclusion for parentage verification and probability of match for identity in American kennel club breeds using 17 canine microsatellite markers. Anim. Genet. 35, $14-17$

Detilleux, J.C., Koehler, K.J., Freeman, A.E., Kehrli, M.E., Kelley, D.H., 1994. Immunological parameters of periparturient Holstein cattle: genetic variation. J. Dairy Sci. 77, 2640-2650.

Detilleux, J.C., Leroy, P.L., 2000. Application of a mixed normal mixture model for the estimation of mastitis-related parameters. J. Dairy Sci. $83,2341-2349$.

Duchemin, S.I., Colombani, C., Legarra, A., Baloche, G., Larroque, H., Astruc, J.M., Barillet, F., Robert-Granié, C., Manfredi, E., 2012. Genomic selection in the French Lacaune dairy sheep breed. J. Dairy Sci. 95, 2723-2733.

El-Saied, U.M., Carriedo, J.A., De la Fuente, L.F., San Primitivo, F., 1999. Genetic parameters of lactation cell counts and milk and protein yields in dairy ewes. J. Dairy Sci. 82, 639-644.

El-Saied, U.M., Carriedo, J.A., San Primitivo, F., 1998. Heritability of test day somatic cell counts and its relationship with milk yield and protein percentage in dairy ewes. J. Dairy Sci. 81, 2956-2961.

Fox, L.K., Gay, J.M., 1993. Contagious mastitis. Vet. Clin. North Am. Food Anim. Pract. 9, 475-487.

Fthenakis, G.C., El-Masannat, E.T.S., Booth, J.M., Jones, J.E.T., 1991. Somatic cell count of ewes' milk. Br. Vet. J. 147, 575-581.

Gianola, D., Odegard, J., Heringstad, B., Klemetsdal, G., Sorensen, D., Madsen, P., Jensen, J., Detilleux, J., 2004. Mixture model for inferring susceptibility to mastitis in dairy cattle: a procedure for likelihoodbased inference. Genet. Sel. Evol. 36, 3-27.

Glowatzki-Mullis, M.L., Muntwyler, J., Gaillard, C., 2007. Cost-effective parentage verification with 17-plex PCR for goats and 19-plex PCR for sheep. Anim. Genet. 38, 86-88.

Goddard, M.E., Hayes, B.J., 2007. Genomic selection. J. Anim. Breed. Genet. $124,323-330$

González-Rodríguez, M.C., Cármenes, P., 1996. Evaluation of the California mastitis test as a discriminant method to detect subclinical mastitis in ewes. Small Rumin. Res. 21, 245-250.

González-Rodríguez, M.C., Gonzalo, C., San Primitivo, F., Carmenes, P., 1995. Relationship between somatic cell count and intramammary infection of the half udder in dairy ewes. J. Dairy Sci. 78, 2753-2759.

Gonzalo, C., Ariznabarreta, A., Tardáguila, J.A., San Primitivo, F., 1998. Factores infecciosos de variación del recuento celular de la leche de oveja [Infectious factors of the variation of cell count in sheep milk]. Ovis $56,27-34$

Gutierrez-Gil, B., El-Zarei, M.F., Bayon, Y., Alvarez, L., de la Fuente, L.F., San Primitivo, F., Arranz, J.J., 2007. Detection of quantitative trait loci influencing somatic cell score in Spanish Churra sheep. J. Dairy Sci. 90, 422-426.

Hamann, H., Horstick, A., Wessels, A., Distl, O., 2004. Estimation of genetic parameters for test day milk production, somatic cell score and litter size at birth in East Friesian ewes. Livest. Prod. Sci. 87, 153-160.

Harmon, R.J., 1994. Physiology of mastitis and factors affecting somatic cell counts. J. Dairy Sci. 77, 2103-2112. 
Heringstad, B., Klemetsdal, G., Ruane, J., 2000. Selection for mastitis resistance in dairy cattle: a review with focus on the situation in the Nordic countries. Livest Prod. Sci. 64, 95-106.

Huntley, S.J., Cooper, S., Bradley, A.J., Green, L.E., 2012. A cohort study of the associations between udder conformation, milk somatic cell count, and lamb weight in suckler ewes. J. Dairy Sci. 95, 5001-5010.

Jones, J.E.T., 1991. Mastitis in sheep. In: Owen, J.B., Axford, R.F.E. (Eds.), Breeding for Disease Resistance in Farm Animals. CAB International, Wallingford, UK, p. 412.

Kehrli, M.E., Shuster, D.E., 1994. Factors affecting milk somatic cells and their role in health of the bovine mammary gland. J. Dairy Sci. 77, 619-627.

Klungland, H., Sabry, A., Heringstad, B., Olsen, H.G., Gomez-Raya, L., Vage, D.I., Olsaker, I., Odegard, J., Klemetsdal, G., Schulman, N., Vilkki, J., Ruane, J., Aasland, M., Ronningen, K., Lien, S., 2001. Quantitative trait loci affecting clinical mastitis and somatic cell count in dairy cattle. Mamm. Genome 12, 837-842.

Lee, C., Pollak, E.J., 1997. Influence of sire misidentification on sire $\mathrm{x}$ year interaction variance and direct-maternal genetic covariance for weaning weight in beef cattle. J. Anim. Sci. 75, 2858-2863.

Legarra, A., Ramon, M., Ugarte, E., Perez-Guzman, M.D., Arranz, J., 2007. Economic weights of somatic cell score in dairy sheep. Animal 1, 205-212.

Legarra, A., Ugarte, E., 2005. Genetic parameters of udder traits, somatic cell score, and milk yield in Latxa sheep. J. Dairy Sci. 88, 2238-2245.

Leitner, G., Chaffer, M., Caraso, Y., Ezra, E., Kababea, D., Winkler, M., Glickman, A., Saran, A., 2003. Udder infection and milk somatic cell count, NAGase activity and milk composition-fat, protein and lactose-in Israeli-Assaf and Awassi sheep. Small Rumin. Res. 49, 157-164.

Leitner, G., Merin, U., Krifucks, O., Blum, S., Rivas, A.L., Silanikove, N., 2012. Effects of intra-mammary bacterial infection with coagulase negative staphylococci and stage of lactation on shedding of epithelial cells and infiltration of leukocytes into milk: comparison among cows, goats and sheep. Vet. Immunol. Immunopathol. 147, 202-210.

Leitner, G., Silanikove, N., Merin, U., 2008. Estimate of milk and curd yield loss of sheep and goats with intramammary infection and its relation to somatic cell count. Small Rumin. Res. 74, 221-225.

Madsen, P., Shariati, M.M., Odegard, J., 2008. Genetic analysis of somatic cell score in Danish Holsteins using a liability-normal mixture model. J. Dairy Sci. 91, 4355-4364.

Maisi, P., Junttila, J., Seppanen, J., 1987. Detection of subclinical mastitis in ewes. Br. Vet. J. 143, 402-409.

Marco, J.C., Romero, M., Salazar, L.M., Pérez, I., Marín, C., 1991. Estudio microbiológico sobre mamitis ovinas en la oveja lacha [Microbiological study on ovine mastitis in lacha sheep]. ITEA 11, 721-723.

Mavrogenis, A.P., Koumas, A., Gavrielidis, G., 1999. The inheritance of somatic cell counts (index of mastitis) in Chios sheep. In: Barillet, F., Deligeorgis, S., Zervas, N.P., Boyazoglu, J.G., Vallerand, F. (Eds.), Milking and Milk. Production of Dairy Sheep and Goats. , pp. 389-392.

McDougall, S., Murdough, P., Pankey, W., Delaney, C., Barlow, J., Scruton, D., 2001. Relationships among somatic cell count, California mastitis test, impedance and bacteriological status of milk in goats and sheep in early lactation. Small Rumin. Res. 40, 245-254.

McLachlan, G., Peel, D., 2000. Finite Mixture Models, 1st ed. Wiley, New York.

Miller, G.Y., Bartlett, P.C., Lance, S.E., Anderson, J., Heider, L.E., 1993. Cost of clinical mastitis and mastitis prevention in dairy herds. J. Am. Vet. Med. Assoc. 202, 1230-1236.

Mrode, R.A., Swanson, G.J.T., Winters, M.S., 1998. Genetic parameters and evaluations for somatic cell counts and its relationship with production and type traits in some dairy breeds in the United Kingdom. Anim. Sci. 66, 569-576.

Mulder, H.A., Bijma, P., 2005. Effects of genotype x environment interaction on genetic gain in breeding programs. J. Anim. Sci. 83, 49-61.

Mulder, H.A., Veerkamp, R.F., Ducro, B.J., van Arendonk, J.A.M., Bijma, P., 2006. Optimization of dairy cattle breeding programs for different environments with genotype by environment interaction. J. Dairy Sci. 89, 1740-1752.

Ødegård, J., Jensen, J., Madsen, P., Gianola, D., Klemetsdal, G., Heringstad, B., 2003. Detection of mastitis in dairy cattle by use of mixture models for repeated somatic cell scores: a Bayesian approach via Gibbs sampling. J. Dairy Sci. 86, 3694-3703.

Othmane, M.H., De La Fuente, L.F., Carriedo, J.A., San Primitivo, F., 2002. Heritability and genetic correlations of test day milk yield and composition, individual laboratory cheese yield, and somatic cell count for dairy ewes. J. Dairy Sci. 85, 2692-2698.

Pengov, A., 2001. The role of coagulase-negative Staphylococcus spp. and associated somatic cell counts in the ovine mammary gland. J. Dairy Sci. $84,572-574$
Peris, C., Diaz, J.R., Fernandez, N., Rodriguez, M., 1996. Effect of subclinical mastitis on milk yield in Manchega ewes: preliminary results. In: Rubino, R. (Ed.), Somatic Cells and Milk of Small Ruminants. , pp. 203-206.

Persson-Waller, K., Colditz, I.G., Seow, H.F., 1997. Accumulation of leucocytes and cytokines in the lactating ovine udder during mastitis due to Staphylococcus aureus and Escherichia coli. Res. Vet. Sci. 62, 63-66.

Philipsson, J., Ral, G., Berglund, B., 1995. Somatic cell count as a selection criterion for mastitis resistance in dairy cattle. Livest Prod. Sci. 41, 195-200.

Pirisi, A., Lauret, A., Dubeuf, J.P., 2007. Basic and incentive payments for goat and sheep milk in relation to quality. Small Rumin. Res. 68, 167-178.

Raadsma, H.W., Jonas, E., McGill, D., Hobbs, M., Lam, M.K., Thomson, P.C., 2009. Mapping quantitative trait loci (QTL) in sheep II. Meta-assembly and identification of novel QTL for milk production traits in sheep. Genet. Sel. Evol. 41, 45

Radostits, O.M., Gay, C.C., Hinchcliff, K.W., Constable, P.D., 2007. Ovine progressive pneumonia (Maedi-Visna). In: Carlos, C. (Ed.), Veterinary Medicine. Saunders Elsevier, Philadelphia, pp. 1362-1366.

Riggio, V., Finocchiaro, R., van Kaam, J.B.C.H.M., Portolano, B., Bovenhuis, H., 2007. Genetic parameters for milk somatic cell score and relationships with production traits in primiparous dairy sheep. J. Dairy Sci. 90, 1998-2003.

Riggio, V., Pesce, L.L., Morreale, S., Portolano, B., 2013. Receiver-operating characteristic curves for somatic cell scores and California mastitis test in Valle del Belice dairy sheep. Vet. J. 196, 528-532.

Riggio, V., Portolano, B., Bovenhuis, H., Bishop, S.C., 2010. Genetic parameters for somatic cell score according to udder infection status in Valle del Belice dairy sheep and impact of imperfect diagnosis of infection. Genet. Sel. Evol. 42, 30.

Robertson, A., 1959. The sampling variance of the genetic correlation coefficient. Biometrics 15, 469-485.

Ron, M., Blanc, Y., Band, M., Ezra, E., Weller, J.I., 1996. Misidentification rate in the Israeli dairy cattle population and its implications for genetic improvement. J. Dairy Sci. 79, 676-681.

Rosa, A.J.M., Sardina, M.T., Mastrangelo, S., Tolone, M., Portolano, B., 2013. Parentage verification of Valle del Belice dairy sheep using multiplex microsatellite panel. Small Rumin. Res. 113, 62-65.

Rupp, R., Beaudeau, F., Boichard, D., 2000. Relationship between milk somatic-cell counts in the first lactation and clinical mastitis occurrence in the second lactation of French Holstein cows. Prev. Vet. Med. 46, 99-111.

Rupp, R., Bergonier, D., Dion, S., Hygonenq, M.C., Aurel, M.R., RobertGranie, C., Foucras, G., 2009. Response to somatic cell count-based selection for mastitis resistance in a divergent selection experiment in sheep. J. Dairy Sci. 92, 1203-1219.

Rupp, R., Boichard, D., 1999. Genetic parameters for clinical mastitis, somatic cell score, production, udder type traits, and milking ease in first lactation Holsteins. J. Dairy Sci. 82, 2198-2204.

Rupp, R., Boichard, D., 2003. Genetics of resistance to mastitis in dairy cattle. Vet. Res. 34, 671-688.

Rupp, R., Boichard, D., Barbat, A., Astruc, J., Lagriffoul, G., Barillet, F., 2002. Selection for mastitis resistance in French dairy sheep. Proc. 7th World Congr. Genet. Appl. Livest. Prod. 31, 119-122.

Rupp, R., Foucras, G., 2010. Genetics of mastitis in dairy ruminants. In: Bishop, S.C., Axford, R.F.E., Nicholas, F.W., Owen, J.B. (Eds.), Breeding for Disease Resistance in Farm Animals., 3rd edition, pp. 183-212.

Rupp, R., Lagriffoul, G., Astruc, J.M., Barillet, F., 2003a. Genetic parameters for milk somatic cell scores and relationships with production traits in French Lacaune dairy sheep. J. Dairy Sci. 86, 1476-1481.

Rupp, R., Schibler, L., Cribiu, E., Amigues, Y., Boscher, M.Y., Mura, L., Sechi, T., Fraghi, A., Casu, S., Barillet, F., Carta, A., 2003b. Evidence of chromosomal regions controlling somatic cell count in dairy sheep from two QTL detection projects. In: Proc. of the International Workshop on Major Genes and QTL in Sheep and Goat, Toulouse, France.

Samoré, A.B., (PhD thesis) 2003. Genetics aspects of somatic cell count in the Italian Holstein Friesian population. Wageningen University.

Schulman, N.F., Viitala, S.M., de Koning, D.J., Virta, J., Maki-Tanila, A., Vilkki, J.H., 2004. Quantitative trait loci for health traits in Finnish Ayrshire cattle. J. Dairy Sci. 87, 443-449.

Sechi, S., Salaris, S., Carta, A.S.C., 2007. Relationships between SCC and udder morphology traits in Sardinian sheep. In: Book of abstract, 5th International Symposium on the Challenge to Sheep and Goat Milk Sectors, Alghero, Italy, p. 68.

Serrano, M., Pérez-Guzmán, M.D., Montoro, V., Jurado, J.J., 2003. Genetic analysis of somatic cell count and milk traits in Manchega ewes: mean lactation and test-day approaches. Livest. Prod. Sci. 84, 1-10. 
Seyedabadi, H., Amirinia, C., Banabazi, M.H., Emrani, H., 2006. Parentage verification of Iranian Caspian horse using microsatellites markers. Iran. J. Biotechnol. 4, 260-264.

ten Napel, J., de Haas, Y., de Jong, G., Lam, T.J.G.M., Ouweltjes, W., Windig, J.J., 2009. Characterization of distributions of somatic cell counts. J. Dairy Sci. 92, 1253-1264.

Tolone, M., Riggio, V., Portolano, B., 2013. Estimation of genetic and phenotypic parameters for bacteriological status of the udder, somatic cell score, and milk yield in dairy sheep using a threshold animal model. Livest. Prod. Sci. 151, 134-139.

Tozaki, T., Kakoi, H., Mashima, S., Hirota, K., Hasegawa, T., Ishida, N., Miura, N., Choi-Miura, N.H., Tomita, M., 2001. Population study and validation of paternity testing for thoroughbred horses by 15 microsatellite loci. J. Vet. Med. Sci. 63, 1191-1197.

Urioste, J.I., Franzen, J., Strandberg, E., 2010. Phenotypic and genetic characterization of novel somatic cell count traits from weekly or monthly observations. J. Dairy Sci. 93, 5930-5941.

Valeeva, N.I., Lam, T.J.G.M., Hogeveen, H., 2007. Motivation of dairy farmers to improve mastitis management. J. Dairy Sci. 90, 4466-4477.

Van Eenennaam, A.L., Weaber, R.L., Drake, D.J., Penedo, M.C.T., Quaas, R.L., Garrick, D.J., Pollak, E.J., 2007. DNA-based paternity analysis and genetic evaluation in a large, commercial cattle ranch setting. J. Anim. Sci. 85, 3159-3169.

Van Vleck, L.D., 1970. Misidentification and sire evaluation. J. Dairy Sci. 53, 1697-1702.

Walawski, K., 1999. Genetic aspects of mastitis resistance in cattle. J. Appl. Genet. 40, 117-128.

Wanner, J.M., Rogers, G.W., Kehrli, M.E., Cooper, J.B., 1998. Intramammary infections in primiparous Holsteins: heritabilities and comparisons of bovine leukocyte adhesion deficiency carriers and noncarriers. J. Dairy Sci. 81, 3293-3299.

Weller, J.I., Saran, A., Zeliger, Y., 1992. Genetic and environmental relationships among somatic cell count, bacterial infection, and clinical mastitis. J. Dairy Sci. 75, 2532-2540.

White, L.J., Schukken, Y.H., Lam, T.J.G., Medley, G.F., Chappell, M.J., 2001. A multispecies model for the transmission and control of mastitis in dairy cows. Epidemiol. Infect. 127, 567-576.

Ziluaga, I., Romeo, M., Marco, J.C., 1998. Prevalencia, patogenicidad y epidemiología de los microorganismos implicados en procesos mamíticos del ganado ovino. Ovis 59, 27-49. 